\title{
PENGARUH KEMAMPUAN KERJA DAN SIKAP MENTAL TERHADAP KINERJA KARYAWAN PADA DIVISI FOOD AND BEVERAGE NOVOTEL BANDUNG
}

\author{
Dhonny Yusuf Amier \\ Sekolah Tinggi Pariwisata Bandung \\ Email: dhonny26fb@gmail.com
}

\begin{abstract}
Penelitian ini difokuskan pada pengaruh kemampuan kerja dan sikap mental terhadap kinerja karyawan di Novotel Bandung. Tujuan penelitian ini untuk mengetahui dan menganalisis pengaruh kemampuan kerja dan sikap mental terhadap kinerja karyawan di Novotel Bandung. Hipotesis yang diajukan dalam penelitian ini terdiri dari 3 hipotesis yaitu : (1) Terdapat pengaruh kemampuan kerja terhadap kinerja karyawan di Novotel Bandung; (2) Terdapat pengaruh sikap mental terhadap kinerja karyawan di Novotel Bandung; (3) Terdapat pengaruh kemampuan kerja dan sikap mental terhadap kinerja karyawan di Novotel Bandung.

Penelitian ini menggunakan jenis penelitian kuantitatif dengan pendekatan verifikatif. Subyek penelitian dilakukan di Novotel Bandung dengan populasinya adalah karyawan hotel Novotel Bandung divisi Food and Beverage Service yang berjumlah 42 orang. Teknik penarikan sampel yang digunakan dalam penelitian ini adalah stratified random sampling dengan rumus slovin sehingga diperoleh sampel sebanyak 30 responden. Teknik pengumpulan data yang digunakan melalui studi kepustakaan, observasi dan penyebaran angket. Teknik analisis data yang digunakan adalah analisis Regresi.

Hasil penelitian membuktikan bahwa Kemampuan Kerja dan Sikap Mental berpengaruh terhadap Kinerja Karyawan di Novotel Bandung. Untuk mengoptimalkan hasil dari penelitian ini, maka diharapkan penelitian yang akan datang mengenai masalah yang sama bisa menambah variabel-variabel lain yang dipandang relevan dan lebih mendalam lagi pembahasannya, misalnya dengan membedakan tingkat kinerja karyawan pada tiap bagian atau unit kerja.
\end{abstract}

Kata kunci: Kemampuan Kerja, Sikap Mental, Kinerja Karyawan 


\title{
THE INFLUENCE OF WORKING ABILITY AND MENTAL ATTITUDE TO EMPLOYEE PERFORMANCE IN DIVISION FOOD AND BEVERAGE NOVOTEL BANDUNG
}

\begin{abstract}
This study focuses on the influence of the work ability and mental attitude on the performance of the employees at the Novotel Bandung. The purpose of this study is to determine and analyze the influence of the work ability and mental attitude on the performance of the employees at the Novotel Bandung. This study presents three hypotheses, namely: (1) There is an effect of the work ability on the performance of employees at the Novotel Bandung; (2) There is an influence of mental attitude on the performance of employees at the Novotel Bandung; (3) There is influence of the work ability and mental attitude on the performance of the employee at the Novotel Bandung.

This study uses a quantitative approach with explanatory research. The research is conducted at the Novotel Bandung with the population of 42 employees of Food and Beverage Service. The sampling technique used in this study is stratified random sampling and the sample calculation is done by using power test technique with a minimum sample size of 30 respondents. The data collection technique is done through library research, observation and questionnaire and the data analysis technique used is the regression analysis.

The research findings show that the work ability and mental attitude have a significant influence on employee performance at the Novotel Bandung. To optimize the results of this study, it is expected that future studies regarding the same issue could add other relevant variables to the subject with more in-depth discussion, for example by differentiating the levels of employee performance in each section or unit.
\end{abstract}

Keywords: work ability, mental attitude, performance of the employess

\section{PENDAHULUAN}

Pada perkembangan dunia bisnis di Indonesia sekarang ini, perusahaan dituntut untuk mempertahankan dan meningkatkan kualitas kerja dan kuantitas kerja pelayanannya. Hal ini dimaksudkan agar perusahaan dapat bersaing dengan perusahaan lain yang sejenis, baik pada tingkat nasional maupun tingkat internasional. Salah satu bagian penting yang berperan dalam menentukan keberhasilan perusahaan adalah dengan pembinaan tenaga kerja yang potensial. Perusahaan berusaha mencari dan membina karyawan dengan semangat tinggi, menciptakan dan memelihara keunggulan sumber daya manusia yang mampu bersaing. Sumber daya manusia inilah yang pada akhirnya menjadi tulang punggung bagi keberhasilan suatu perusahaan.

Kinerja karyawan merupakan suatu potensi yang harus dimiliki oleh setiap karyawan untuk melaksanakan setiap tugas dan tanggung jawab yang diberikan oleh perusahaan kepada karyawan. Dengan kinerja yang baik, maka setiap karyawan dapat menyelesaikan segala beban perusahaan dengan efekif dan efisien sehingga masalah yang terjadi pada perusahaan dapat teratasi dengan baik. Selain 
itu karyawan merupakan sumber daya utama yang dituntut oleh perusahaan untuk memberikan pelayanan yang terbaik kepada konsumen, sehingga konsumen merasa terlayani dengan baik dan akan merasa puas. Hal ini menunjukkan bahwa kinerja karyawan dapat berpengaruh terhadap kesuksesan perusahaan dalam pencapaian tujuannya.

\section{Sumber Daya Manusia}

Dalam proses pencapaian tujuannya, suatu organisasi memerlukan saranasarana yang dalam ilmu manajemen meliputi : manusia(man), uang (money), metoda (method), peralatan / mesin (machines), bahan (materials), dan pasar (market)yang populer dengan istilah 6M. Tanpa mengabaikan peran penting unsurunsur manajemen lainnya, unsur manusia (man) dipandang paling penting bagi kehidupan organisasi. Pentingnya peran sumber daya manusia dalam organisasi tampak pada gejala-gejala yang menurut Nawawi (dalam Bahrudin, 2012:73) sebagai berikut :

a. Manusia membentuk organisasi

b. Manusia membutuhkan organisasi

c. Organisasi membutuhkan manusia

d. Manusia merupakan motor penggerak organisasi

e. Tanpa manusia organisasi tidak berfungsi

f. Eksistensi organisasi tergantung pada kegiatan manusia

g. Kegiatan manusia yang dominan dalam organisasi disebut bekerja.

Berdasarkan pemahaman tersebut dapat disimpulkan bahwa, sumber daya manusia bagi organisasi berada dalam posisi sentral karena dengan aktivitas yang dijalankannya mempengaruhi sumber daya organisasi lainnya, Simamora (dalam Bahrudin, 2012:84) mengatakan, "Sumber daya manusia membuat sumber daya organisasi lainnya bergerak". Pendapat lain dikemukakan oleh Hasibuan (2010:39) bahwa, "Manusia selalu berperan aktif dan dominan dalam setiap organisasi karena manusia menjadi perencana, pelaku, dan penentu terwujudnya tujuan organisasi". Begitu pentingnya sumber daya manusia yang berkualitas, Remsi (2011:1).

Sumber daya manusia pada dasarnya terdiri dari sumber daya manusia yang telah bekerja (karyawan, pegawai) maupun sumber daya manusia yang belum atau yang tidak bekerja (pelajar, mahasiswa, pengangguran). Dengan demikian, maka pegawai hotel merupakan bagian dari sumber daya manusia secara keseluruhan dan termasuk masuk dalam katagori sumber daya manusia mikro. Pegawai hotel orangorang yang telah terikat atau berhubungan kerja dengan organisasi Hotel berdasarkan suatu kontrak kerja atau ketentuan-ketentuan yang disepakati oleh kedua belah pihak berkaitan dengan penulisan tesis ini, maka pegawai yang bekerja pada Novotel Bandung

\section{Kemampuan Kerja}

Kemampuan kerja adalah suatu kapasitas individu untuk mengerjakan berbagai tugas dalam suatu pekerjaan (Robbins, 2012:92). Istilah kemampuan kerja atau kinerja merupakan pengalih bahasaan dari kata performance. Menurut Bernadin dan Russel (Ruky, 2012:57) definisi performance adalah catatan tentang hasil-hasil yang diperoleh dari fungsi-fungsi pekerjaan tertentu atau kegiatan tertentu selama kurun waktu tertentu. Kemampuan menekankan pengertian sebagai hasil atau apa yang keluar (outcomes) dari sebuah pekerjaan dan kontribusi mereka pada 
organisasi. Jadi kemampuan kerja adalah suatu hasil kerja yang dicapai seseorang dalam melaksanakan tugas-tugas yang dibebankan kepadanya yang didasarkan atas kecakapan, pengalaman dan kesungguhan serta waktu (Hasibuan, 2013:107).

Salah satu faktor yang sangat penting dan berpengaruh terhadap keberhasilan karyawan di dalam melaksanakan suatu pekerjaan adalah kemampuan kerja. Kemampuan merupakan potensi yang ada dalam diri seseorang untuk berbuat sehingga memungkinkan seseorang untuk dapat melakukan pekerjaan ataupun tidak dapat melakukan pekerjaan tersebut.

Untuk mengetahui seseorang karyawan mampu atau tidak dalam melaksanakan pekerjaannya dapat kita lihat melalui beberapa indikator yang ada di bawah ini. Indikator kemampuan kerja adalah sebagai berikut :

1. Kesanggupan Kerja

Kesanggupan kerja karyawan adalah suatu kondisi dimana seorang karyawan merasa mampu menyelesaikan pekerjaan yang diberikan kepadanya.

2. Pendidikan

Pendidikan adalah kegiatan untuk meningkatkan pengetahuan seseorang termasuk di dalamnya peningkatan penguasaan teori dan keterampilan memutuskan terhadap persoalan yang menyangkut kegiatan mencapai tujuan.

3. Masa Kerja

Masa kerja adalah waktu yang dibutuhkan oleh seorang karyawan dalam bekerja pada sebuah perusahaan atau organisasi. (Robbins, 2012:98).

\section{Sikap Mental}

Sikap mental merupakan kondisi yang mendorong diri pegawai untuk berusaha mencapai prestasi kerja secara maksimal. Seorang karyawan harus memiliki sikap mental yang siap secara psikologi (mental, fisik, tujuan dan situasi). Artinya, seorang karyawan harus siap secara mental, maupun secara fisik, memahami tujuan utama dan target kerja yang akan dicapai, mampu memanfaatkan dan menciptakan situasi kerja aman dan nyaman sesama karyawan. Kondisi yang mendorong diri karyawan untuk berusaha mencapai prestasi kerja secara maksimal (La Pierre dalam Azwar, 2010:5).

Untuk mengetahui seseorang karyawan memiliki sikap dan mental yang positif dapat kita lihat melalui beberapa indikator yang ada di bawah ini. Indikator sikap mental adalah sebagai berikut :

1. Motivasi Kerja

Motivasi kerja adalah sesuatu yang menimbulkan dorongan atau semangat kerja atau dengan kata lain pendorong semangat kerja. (Martoyo, 2012:47)

2. Disiplin Kerja

Disiplin kerja dapat diartikan sebagai sikap menghargai, patuh, taat terhadap peraturan dan tata tertib yang berlaku di tempat kerja yang dilakukan secara rela dengan penuh tanggung jawab dan siap untuk menerima sanksi jika melanggar tugas dan wewenang.

3. Etika Kerja

Suatu semangat kerja yang dimiliki oleh masyarakat untuk mampu bekerja lebih baik guna memperoleh nilai hidup mereka. Sukriyanto (2010:35) 


\section{Kinerja Karyawan}

Kinerja adalah merupakan perwujudan hasil kerja yang dilakukan oleh karyawan yang biasanya dipakai sebagai dasar penilaian terhadap karyawan atau organisasi. Kinerja yang baik merupakan suatu langkah untuk menuju tercapainya tujuan organisasi. Oleh karena itu kinerja merupakan sasaran penentu dalam mencapai tujuan organisasi, tetapi hal ini tidak mudah, karena banyak faktor yang mempengaruhi tinggi rendahnya kinerja seseorang.

Keberhasilan suatu organisasi dipengaruhi oleh kinerja (job performance) sumber daya manusia,untuk itu setiap perusahaan akan berusaha untuk meningkatkan kinerja pegawai dalammencapai tujuan organisasi yang telah ditetapkan. Budaya organisasi yang tumbuh dan terpelihara dengan baik akan mampu memacu organisasi ke arah perkembangan yang lebih baik. Disisi lain, kemampuan pemimpin dalam menggerakkan dan memberdayakankan pegawainya akan mempengaruhi kinerja. Istilah kinerja dari kata job performance atau actual performance (prestasi kerja atau prestasi sesungguhnya yang dicapai oleh seseorang). Prestasi kerja pada umumnya dipengaruhi oleh kecakapan, keterampilan, pengalaman dankesungguhan kerja dari tenaga kerja yang bersangkutan.

Ukuran secara kualitatif dan kuantitatif yang menunjukkan tingkatan pencapaian suatu sasaran atau tujuan yang telah ditetapkan adalah merupakan sesuatu yang dapat dihitung serta digunakan sebagai dasar untuk menilai atau melihat bahwa kinerja setiap hari dalam perusahaan dan perseorangan terus mengalami peningkatan sesuai dengan rencana yang telah ditetapkan.

Menurut Mangkunegara (2010:60) kinerja karyawan adalah hasil kerja secara kualitas dan kuantitas yang dicapai oleh seorang karyawan dalam melaksanakan tugasnya sesuai dengan tanggung jawab yang diberikan kepadanya.

Beberapa faktor yang mempengaruhi tingkat kinerja antara lain :

1. Kuantitas kerja yaitu pencapaian kinerja karyawan yang dapat terlihat pada diri karyawan itu sendiri pada saat bekerja, yang meliputi ketetapan waktu dalam mengerjakan pekerjaan, ketelitian dalam mengerjakan tugas dan juga terampil dalam mengerjakan tugas.

2. Kualitas kerja adalah pencapaian kinerja karyawan yang diukur atas hasil pekerjaan yang dicapai pekerja dalam bekerja, kualitas kerja juga dapat diukur oleh output atau hasil kerja dibandingkan dengan standar output yang telah ditetapkan perusahaan.

\section{Pengaruh Kemampuan Kerja dan Sikap Mental terhadap Kinerja Karyawan}

\section{Pengaruh Kemampuan Kerja Terhadap Kinerja Karyawan}

Menurut Nawawi (2013:28) kepentingan para pemimpin terhadap kemampuan kerja seorang karyawan cenderung terpusat pada kinerja karyawan. Pandangan ini mengenai hubungan antara kemampuan kerja karyawan dengan kinerja pada hakekatnya dapat diringkas dalam pernyataan "seorang pekerja yang bahagia adalah seorang pekerja yang produktif" banyak yang dilakukan oleh para pemimpin dalam membuat para pekerjanya merasa senang dalam pekerjaannya. Selain itu bukti yang cukup jelas bahwa karyawan yang memiliki kemampuan kerja yang tinggi mempunyai tingkat keluar dari sebuah organisasi atau perusahaan lebih rendah. Pengaruh kemampuan kerja karyawan terhadap keluarnya karyawan karena ketidakpuasan sering dikaitkan dengan tingkat tuntunan dan keluhan pekerja yang 
tinggi. Sebaliknya angkatan kerja yang memiliki kemampuan kerja yang tinggi akan memberikan produktivitas yang tinggi sehingga kinerja yang tinggi dapat tercapai. Sebuah organisasi atau perusahaan pada dasarnya ingin mendapatkan kinerja karyawan yang baik untuk mencapai tujuan yang ditetapkan. Pihak perusahaan harus memperhatikan kondisi-kondisi dari seluruh karyawannya, diantaranya adalah dengan menumbuhkan kemampuan kerja yang baik bagi para karyawannya.

\section{Pengaruh Sikap Mental Terhadap Kinerja Karyawan}

Menurut Nawawi (2013:33) suasana batin atau psikologi seseorang pekerja sebagai individu dalam masyarakat, organisasi atau perusahaan dalam lingkungan kerjanya, sangat besar pengauhnya pada pelaksanaan pekerjaannya. Suasana batin terlihat dalam semangat atau gairah kerja yang menghasilkan kegiatan kerja sebagai dorongan bagi pencapaian tujuan bisnis organisasi perusahaan tempatnya bekerja. Dari psikologis kenyataannya menunjukkan bahwa gairah atau ketidaksemangatan seorang pekerja dalam melaksanakan pekerjaannya sangat dipengaruhi oleh sikap mental secara psikologi (mental, fisik, tujuan dan situasi) yang mendorongnya. Dengan kata lain setiap karyawan dapat mencapai prestasi kerja secara maksimal serta tujuan dan target kerja dapat tercapai.

\section{A. Kerangka Konseptual}

Dalam hal ini penulis melihat adanya hubungan yang saling terkait antara variabel-varaibel yang akan penulis teliti dan akan penulis uji pula melalui pengujian hipotesis.

Ditinjau dari jenis hubungan variabel, maka disini ternasuk hubungan sebab akibat yaitu suatu variabel dapat mempengaruhi variabel yang lain, sehingga variabel bebas (independent variable) adalah kemampuan kerja (X1) yang terdiri dari kesanggupan kerja, pendidikan, masa kerja serta sikap mental (X2) yang terdiri dari motivasi kerja, disiplin kerja, dan etika kerja. Sedangkan variabel terikat (dependent variable) adalah kinerja karyawan (Y) yang terdiri dari kualitas kerja dan kuantitas kerja.

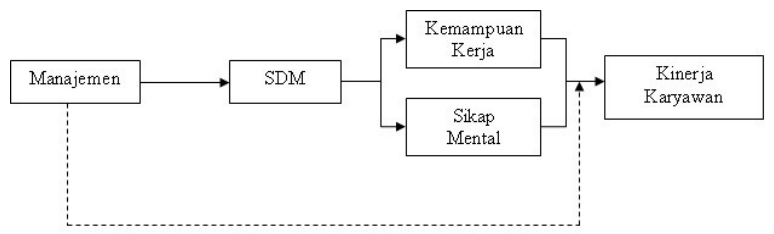

Gambar Kerangka Konseptual

\section{METODOLOGI}

Penelitian ini menggunakan metode kuantitatif. Pengertian metode kuantitatif menurut Sugiyono (2014:2) adalah suatu metode untuk meneliti pada populasi atau sampel tertentu, pengumpulan data bersifat kuantitatif dengan tujuan untuk menguji hipotesis yang telah ditetapkan. Penelitian ini menggunakan metode penelitian kuantitatif dengan pendekatan verifikatif. Metode verifikatif diartikan sebagai penelitian yang dilakukan terhadap populasi atau sampel tertentu dengan tujuan untuk menguji hipotesis yang telah ditetapkan (Sugiyono, 2014:8). Alat analisis 
yang digunakan dalam penelitian ini adalah Regresi Berganda (Multiple Regression).

\section{a. Lokasi dan Objek Penelitian}

Pengumpulan data dilakukan di Novotel Bandung yang terletak di jalan Cihampelas no 23.25 Bandung pada bagian Traning Departement.

\section{Populasi dan Sampel Penelitian}

Populasi adalah wilayah generalisasi yang terdiri atas objek dan sub objek yang mempunyai kualitas dan karakteristik tertentu yang diterapkan peneliti untuk dipelajari dan kemudian ditarik kesimpulannya (Sugiyono, 2014), Peneliti menetapkan populasi dalam penelitian ini adalah karyawan di divisi Food \& Beverage Novotel Bandung sejumlah 42 orang.

Sampel adalah bagian dari jumlah karakteristik yang dimiliki oleh populasi tersebut (Sugiyono, 2014). Untuk pengambilan sampel dari populasi yang berjumlah 42 orang karyawan tersebut peneliti menggunakan rumus Slovin (Umar, 2010).

$$
n=\frac{N}{1+N e^{2}}=\frac{42}{1+42(0,1)^{2}}=29,5 \approx 30
$$

Berdasarkan hasil perhitungan diatas, maka ukuran sampel yang diambil sebesar 30 responden dalam hal ini adalah karyawan divisi Food \& Beverage Novotel Bandung.

\section{c. Definisi Operasional}

Variabel penelitian yang digunakan dalam penelitian ini memiliki dimensi operasional sebagai berikut :

a. Kemampuan Kerja

Suatu kapasitas individu untuk mengerjakan berbagai tugas dalam suatu pekerjaan (Robbins, 2012:92).

Dimensi : (1) Kesanggupan kerja, (2) Pendidikan, (3) Masa kerja.

b. Sikap Mental

Kondisi yang mendorong diri karyawan untuk berusaha mencapai prestasi kerja secara maksimal (La Pierre dalam Azwar, 2010:5).

Dimensi : (1) Motivasi kerja, (2) Disiplin kerja, (3) Etika kerja.

c. Kinerja Karyawan

Hasil kerja secara kualitas dan kuantitas yang dicapai oleh karyawan dalam melaksanakan tugasnya sesuai dengan tanggung jawab yang diberikan kepadanya (Mangkunegara, 2010:60).

Dimensi : (1) Kualitas kerja, (2) Kuantitas kerja.

\section{d. Teknik Pengumpulan Data}

Dalam penelitian ini penyusun menggunakan beberapa teknik pengumpulan data, diantaranya:

a. Observasi

Menurut Sugiyono (2014:166) teknik pengumpulan data dengan observasi digunakan bila penelitian berkenaan dengan perilaku manusia,proses 
kerja,gejala-gejala alam dan bila responden yang diamati tidak terlalu besar. Dalam pelaksanaanya penulis secara langsung mengadakan observasi di Novotel.

b. Kuesioner

Melalui cara pengisian kuesioner proses pengumpulan data akan menjadi lebih akurat dan berdasarkan fakta yang ada. Di dalam penelitian yang penulis lakukan ini jumlah responden yang diberikan pada karyawan novotel.

c. Dokumentasi

Data yang dikumpulkan dalam bentuk laporan-laporan atau data yang telah di publikasikan dengan mempelajari buku-buku yang berkaitan dengan permasalahan yang dibahas dalam pembuatan tesis ini.

\section{e. Pengukuran Instrumen}

Ketetapan suatu pengujian sangat tergantung pada kualitas data yang dipakai dalam pengujian tersebut. Oleh karena itu instrumen yang dipakai untuk mengumpulkan data harus valid dan reliabel.

\section{a. Uji Validitas}

Uji validitas merupakan pengujian item pertanyaan per variabel untuk menunjukkan sejauh mana ketepatan dan kecermatan suatu alat ukur untuk melakukan fungsinya. Untuk menguji validitas kuesioner digunakan rumus kolerasi Product Moment Pearson. Dengan kriteria jika diperoleh thitung $>$ tabel, butir pertanyaan tersebut valid, tetapi jika thitung $>t_{t a b e l}$, maka butir pertanyaan tersebut tidak valid.

\section{b. Uji Reliabilitas}

Reliabilitas adalah tingkat kestabilan suatu alat ukur dalam mengukur suatu gejala. Pada penelitian ini pengujian reliabilitas menggunakan nilai Alpha Cronbach. Menurut Rangkuti (2014) hasil pengukuran dikatakan reliabel jika memiliki nilai Alpha Cronbach minimal sebesar 0,6.

\section{f. Model Regresi Berganda}

Model regresi yang digunakan benar-benar menunjukkan hubungan yang signifikan dan representative atau disebut BLUE (Best Linier Unbiased Estimator) jika model tersebut memenuhi asumsi dasar klasik regresi. Model Regresi yang digunakan sebagai berikut :

$$
\mathrm{Y}=\mathrm{a}+\mathrm{b}_{1} \mathrm{X}_{1}+\mathrm{b}_{2} \mathrm{X}_{2}+\mathrm{e}
$$

\section{Dimana :}

$$
\begin{array}{ll}
\mathrm{Y} & =\text { Kinerja Karyawan } \\
\mathrm{X}_{1} & =\text { Kemampuan Kerja } \\
\mathrm{X}_{2} & =\text { Sikap Mental } \\
\mathrm{a} & =\text { Konstanta regresi } \\
\mathrm{b}_{1-2} & =\text { Koefisien regresi } \\
\mathrm{e} & =\text { Error Terms }
\end{array}
$$




\section{g. Pengujian Hipotesis}

Pengujian Hipotesis dalam penelitian ini dengan cara membandingkan antara nilai thitung untuk pengujian parsial dan $F_{\text {hitung }}$ untuk simultan dengan tingkat signifikansi sebesar 0,05 (5\%), dengan ketentuan sebagai berikut :

1. Pengaruh Parsial

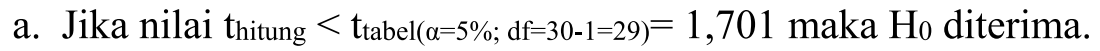

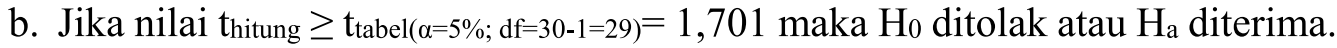

2. Pengaruh Simultan

a. Jika nilai $F_{\text {hitung }}<\mathrm{F}_{\text {tabel }(\alpha=5 \%}$; df $\left.1=2 ; \mathrm{df} 2=30-2-1=27\right)=3,34$ maka $\mathrm{H}_{0}$ diterima.

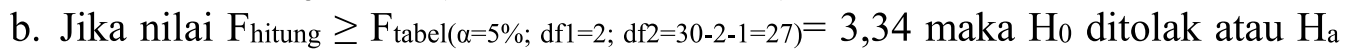
diterima.

\section{HASIL DAN PEMBAHASAN}

\section{Hasil Penelitian}

\section{a. Profil Hotel Novotel Bandung}

Hotel Novotel Bandung berdiri pada tanggal 10 Desember 2006. Lebih dari tiga dekade menjadi salah satu kelompok hotel kelas bisnis yang terkenal didunia. Hotel Novotel Bandung mengembangkan lebih dari 370 hotel dalam 61 negara, termasuk 64 wilayah Asia Pasifik. Novotel berada di kota-kota besar, wilayah dan lokasi resort. Salah satunya berada di Bandung, lokasi Hotel Novotel di Bandung yang sangat strategis yaitu di Jalan Cihampelas no.23-25 yang termasuk berada di pusat kota yang mudah dijangkau yaitu 10 menit dari Bandara Udara Husein Sastranegara, stasiun kereta api dan gerbang tol yang dapat memudahkan tamu untuk mencapai fasilitas kota seperti pusat perbelanjaan dan hiburan serta area perkantoran dengan mudah dan cepat.

\section{b. Pengujian Instrumen Penelitian}

\section{Uji Validitas}

Uji validitas dilakukan dengan menggunakan perhitungan product moment terhadap item-item kuesioner dengan program komputer statistik. Dasar pertimbangan untuk mengukur valid tidaknya kuesioner adalah dengan membandingkan antara thitung $\left(\mathrm{r}_{\mathrm{xy}}\right)$ terhadap tabel. Adapun hasil uji tersebut adalah sebagai berikut.

Tabel 1.

Hasil Uji Validitas Pertanyaan Tentang Kemampuan Kerja

\begin{tabular}{|c|c|c|c|c|}
\hline Variabel & Item & t hitung & t tabel & Ket \\
\hline $\mathrm{X}_{1}:$ Kemampuan Kerja & 1 & 4,574 & 1,701 & Valid \\
& 2 & 3,911 & 1,701 & Valid \\
& 3 & 7,365 & 1,701 & Valid \\
& 4 & 6,227 & 1,701 & Valid \\
& 5 & 3,231 & 1,701 & Valid \\
& 6 & 2,396 & 1,701 & Valid \\
& 7 & 1,677 & 1,701 & Valid \\
& 8 & 2,233 & 1,701 & Valid \\
& 9 & 2,621 & 1,701 & Valid \\
& 10 & 2,016 & 1,701 & Valid \\
& 11 & 2,058 & 1,701 & Valid \\
\hline
\end{tabular}

Sumber : Hasil Pengolahan Data Primer Penelitian Tahun 2014 
Tabel 2.

Hasil Uji Validitas Pertanyaan Tentang Sikap Mental

\begin{tabular}{|c|c|c|c|c|}
\hline Variabel & Item & t hitung & t tabel & Ket \\
\hline $\mathrm{X}_{2}$ : Sikap Mental & 1 & 5,865 & 1,701 & Valid \\
& 2 & 1,77 & 1,701 & Valid \\
& 3 & 1,77 & 1,701 & Valid \\
& 4 & 2,281 & 1,701 & Valid \\
& 5 & 2,277 & 1,701 & Valid \\
& 6 & 1,834 & 1,701 & Valid \\
& 7 & 6,564 & 1,701 & Valid \\
& 8 & 2,491 & 1,701 & Valid \\
& 9 & 1,908 & 1,701 & Valid \\
& 10 & 6,564 & 1,701 & Valid \\
& 11 & 6,564 & 1,701 & Valid \\
& 12 & 2,491 & 1,701 & Valid \\
& 13 & 2,181 & 1,701 & Valid \\
& 14 & 2,715 & 1,701 & Valid \\
& 15 & 2,146 & 1,701 & Valid \\
\hline
\end{tabular}

Sumber : Hasil Pengolahan Data Primer Penelitian Tahun 2014

Tabel 3.

Hasil Uji Validitas Pertanyaan Tentang Kinerja Karyawan

\begin{tabular}{|c|c|c|c|c|}
\hline Variabel & Item & t hitung & t tabel & Ket \\
\hline Y : Kinerja Karyawan & 1 & 2,688 & 1,701 & Valid \\
& 2 & 5,087 & 1,701 & Valid \\
& 3 & 6,940 & 1,701 & Valid \\
& 4 & 3,553 & 1,701 & Valid \\
& 5 & 4,775 & 1,701 & Valid \\
& 6 & 1,781 & 1,701 & Valid \\
& 7 & 4,534 & 1,701 & Valid \\
\hline
\end{tabular}

Sumber : Hasil Pengolahan Data Primer Penelitian Tahun 2014

\section{Uji Reliabilitas}

Untuk mengetahui reliabilitas dari pertanyaan-pertanyaan dalam kuesioner, digunakan teknik Cronbach's Alpha. Adapun hasil uji realiabel tersebut adalah sebagai berikut

Tabel 4.

Tabel Hasil Uji Reliabilitas

\begin{tabular}{|l|c|c|}
\hline \multicolumn{1}{|c|}{ Variabel } & $\begin{array}{c}\text { Cronbach } \\
\text { Alpha }\end{array}$ & Ket \\
\hline $\mathrm{X}_{1}$ : Kemampuan Kerja & 0,712 & Reliabel \\
$\mathrm{X}_{2}$ : Sikap Mental & 0,773 & Reliabel \\
$\mathrm{Y}$ : Kinerja Karyawan & 0,686 & Reliabel \\
\hline
\end{tabular}

Sumber : Hasil Pengolahan Data Primer Penelitian Tahun 2014

Hasil pengujian reliabilitas terhadap seluruh item pertanyaan diperoleh nilai Cronbach Alpha lebih besar 0.6 sehingga dapat disimpulkan bahwa seluruh item 
pertanyaan penelitian ini telah memenuhi syarat reliabilitas atau dengan kata lain bahwa kuesioner ini reliabel sebagai instrumen penelitian.

\section{c. Analisis Regresi Berganda}

Sebelum melakukan analisis regresi linier berganda, ada beberapa asumsi yang harus dipenuhi yaitu Uji Normalitas, uji Multikolinieritas, Uji Heteroskedastisitas dan Uji Autokorelasi.

\section{Uji Normalitas}

Hasil uji normalitas menunjukkan asymp.sig. Kolmogorov-Smirnov pada variabel kemampuan kerja sebesar 0,2, sikap mental sebesar 0,2 dan kinerja karyawan 0,087. Dari hasil tersebut menunjukkan nilai signifikansi atau probabilitas lebih besar dari taraf signifikan 5\% yang berarti ketiga variabel berdistribusi normal

\section{Uji Multikolinieritas}

Multikolinieritas merupakan suatu gejala yang terjadi pada sampel, pada salah satu asumsi regresi liner berganda adalah bahwa tidak terjadi korelasi yang signifikan antar variabel bebasnya. Cara untuk menguji tidak adanya Multikolinieritas dapat dilihat pada Tolerance Value atau Variance Inflantion Faktor (VIF). Variabel penelitian menunjukkan bahwa nilai VIF variabel kurang dari nilai 10. Dengan demikian pada model regresi yang digunakan tidak terjadi multikolinieritas.

\section{Uji Heteroskedatisitas}

Model regresi yang baik adalah tidak memenuhi heteroskedastisitas. Nilai $t$ pada variabel penelitian ini memiliki nilai taraf 5\%, sehingga model regresi dalam penelitian ini tidak terdapat heteroskedastisitas atau terpenuhi asumsi homoskedastisitas.

\section{Model Analisis Regresi Berganda}

Analisis yang digunakan dalam penelitian ini adalah analisis regresi linear berganda yaitu untuk mengetahui pengaruh kemampuan kerja dan sikap mental terhadap kinerja karyawan. Berdasarkan hasil pengujian dengan menggunakan SPSS 17.0 diperoleh hasil sebagai berikut:

Tabel 5.

Hasil Analisis Regresi Berganda

\begin{tabular}{|l|c|c|c|}
\hline \multicolumn{1}{|c|}{ Variabel } & $\begin{array}{c}\text { Koefisien } \\
\text { Regresi }\end{array}$ & $\begin{array}{c}\text { Standar } \\
\text { Error }\end{array}$ & $\begin{array}{c}\mathrm{t} \\
\text { hitung }\end{array}$ \\
\hline Kemampuan Kerja $\left(\mathrm{X}_{1}\right)$ & 0,184 & 0.149 & $\mathbf{2 . 2 3 9}$ \\
Sikap Mental $\left(\mathrm{X}_{2}\right)$ & $\mathbf{0 . 0 9 3}$ & 0110 & $\mathbf{2 . 8 4 6}$ \\
Konstanta & 12.917 & & \\
R & 0,290 & & \\
R Square & $\mathbf{0 , 0 8 4}$ & & \\
F & 11.240 & & \\
\hline
\end{tabular}

Berdasarkan hasil perhitungan analisis regresi berganda maka persamaan adalah sebagai berikut :

$$
\mathrm{Y}=12,917+0,184 \mathrm{X}_{1}+0,093 \mathrm{X}_{2}
$$

Persamaan dari analisis regresi berganda yang tersaji di atas dapat dijelaskan sebagai berikut: 
a) Konstanta sebesar 12,917 menunjukkan rata-rata skor Kinerja Karyawan jika Kemampuan Kerja dan Sikap Mental bernilai nol.

b) Koefisien regresi untuk variabel Kemampuan Kerja $\left(\mathrm{X}_{1}\right)$ adalah 0,184 yang menunjukkan besar perubahan rata-rata skor Kinerja Karyawan yang dipengaruhi oleh Kemampuan Kerja, tanda positif menunjukkan pengaruh yang terjadi adalah berlawanan artinya setiap terjadi peningkatan skor pada skor variabel Kemampuan Kerja sebesar 1 satuan dan variabel lainnya dianggap konstan, maka Kinerja Karyawan diprediksikan akan meningkat sebesar 0,184 satuan.

c) Koefisien regresi untuk variabel Sikap Mental $\left(\mathrm{X}_{2}\right)$ adalah 0,093 yang menunjukkan besar perubahan rata-rata skor Kinerja Karyawan yang dipengaruhi oleh Sikap Mental, tanda positif menunjukkan pengaruh yang terjadi adalah berlawanan artinya setiap terjadi peningkatan skor pada skor variabel Sikap Mental sebesar 1 satuan dan variabel lainnya dianggap konstan, maka Kinerja Karyawan diprediksikan akan meningkat sebesar 0,093 satuan.

\section{Pengujian Hipotesis}

\section{a. Pengaruh Kemampuan Kerja terhadap Kinerja Karyawan}

Berdasarkan hasil pengujian secara parsial diperoleh nilai thitung $(2,239)>$ tabel $(1,7011)$ sehingga hipotesis nol $\left(\mathrm{H}_{0}\right)$ ditolak, yang berarti kemampuan kerja berpengaruh signifikan terhadap kinerja karyawan, sehingga apabila kemampuan kerja semakin baik maka kinerja karyawana di Novotel Bandung akan mengalami kenaikan.

\section{b. Pengaruh Sikap Mental terhadap Kinerja Karyawan}

Berdasarkan hasil pengujian secara parsial diperoleh nilai thitung $(2,846)>t_{\text {tabel }}$ $(1,7011)$ sehingga hipotesis nol $\left(\mathrm{H}_{0}\right)$ ditolak, yang berarti sikap mental berpengaruh signifikan terhadap kinerja karyawan, sehingga apabila sikap mental semakin baik maka kinerja karyawana di Novotel Bandung akan mengalami kenaikan.

\section{c. Pengaruh Kemampuan Kerja dan Sikap Mental terhadap Kinerja}

\section{Karyawan}

Berdasarkan hasil pengujian secara simultan diperoleh nilai $F_{\text {hitung }}(11,24)>$ $\mathrm{F}_{\text {tabel }}(3,34)$ sehingga hipotesis nol $\left(\mathrm{H}_{0}\right)$ ditolak, yang berarti berarti secara simultan ada pengaruh yang signifikan antara variabel kemampuan kerja dan sikap mental terhadap variabel kinerja karyawan.

\section{Pembahasan}

Kemampuan kerja sangat menentukan kinerja karyawan dalam sebuah perusahaan atau organisasi tersebut. Keberhasilan dan kecakapan pelaksanaan pekerjaan dalam suatu organisasi sangat bergantung pada kinerja karyawannya. Sehingga kemampuan kerja merupakan hal penting bagi seorang karyawan untuk dapat menyelesaikan pekerjaan dengan baik. Sebagaimana menurut Soeroto (2012) untuk meningkatkan kemampuan kerja karyawan ada tiga komponen yang meliputi : pertama, upaya mengembangkan dan memelihara pertumbuhan rohani dan jasmani serta usaha menjaga kesehatan. Jika seseorang memiliki pertumbuhan fisik dan psikis yang kuat maka ia akan memiliki potensi dan peluang yang besar untuk ditumbuhkan dan dikembangkan kemampuan kerjanya. Kedua upaya bukan hanya terbatas pada kemampuan ratio dan fisik untuk memecahkan masalah-masalah yang dihadapi dalam jangka pendek, akan tetapi mencakup ketahanan, keuletan fisik dan 
mental dalam mengatasi berbagai kesulitan dan tekanan dalam pekerjaan sehingga selesai dan mencapai hasil.

Demikian halnya pengaruh sikap mental merupakan kondisi yang mendorong diri pegawai untuk berusaha mencapai prestasi kerja secara maksimal. Seorang karyawan harus memiliki sikap mental yang siap secara psikologi (mental, fisik, tujuan dan situasi). Artinya, seorang karyawan harus siap secara mental, maupun secara fisik, memahami tujuan utama dan target kerja yang akan dicapai, mampu memanfaatkan dan menciptakan situasi kerja aman dan nyaman sesama karyawan. Maka dari hasil penelitian menunjukkan adanya pengaruh dari sikap mental terhadap kinerja karyawan Novotel Bandung, yang berarti semakin tinggi atau semakain baik sikap mental karyawan, maka akan meningkat pula pencapaian kinerjanya.

Dengan demikian kedua faktor dalam penelitian ini yaitu kemampuan kerja dan sikap mental merupakan komponen dari kepuasan yang ingin dirasakan oleh karyawan khususnya di Novotel Bandung sehingga dapat mendukung tercapainya kinerja. Seorang karyawan akan memiliki kinerja yang baik, jika memiliki keinginan, harapan, kebutuhan, tujuan, sasaran, dorongan dan insentif yang didukung dengan kemampuan kerja yang baik. Sehingga dengan sikap mental yang baik serta meningkatkan kemampuan kerja karyawan maka dapat meningkatkan kinerja karyawan di Novotel Bandung, agar mampu mempertahankan perusahaan dan tetap eksis pada era persaingan yang ketat ini.

\section{SIMPULAN}

Berdasarkan hasil analisis data tersebut diatas dapat diambil kesimpulan sebagai berikut :

1. Kemampuan kerja berpengaruh signifikan terhadap kinerja karyawan berdasarkan hasil pengujian parsial untuk kemampuan kerja diperoleh nilai thitung $(2,239)>$ tabel $(1,7011)$ sehingga hipotesis nol $\left(\mathrm{H}_{0}\right)$ ditolak. Kondisi tersebut menunjukkan bahwa kemampuan kerja dapat meningkatkan tingkat kinerja karyawan di Novotel Bandung.

2. Sikap mental berpengaruh signifikan terhadap kinerja karyawan di Novotel Bandung. Berdasarkan hasil pengujian parsial sikap mental thitung $(2,846)>t_{\text {tabel }}$ $(1,7011)$ sehingga hipotesis nol $\left(\mathrm{H}_{0}\right)$ ditolak. Dengan ditolaknya $\mathrm{H}_{0}$ berarti sikap mental berpengaruh signifikan terhadap kinerja karyawan, sehingga apabila sikap mental semakin baik maka tingkat kinerja karyawan di Novotel Bandung akan mengalami kenaikan.

3. Secara simultan kemampuan kerja dan sikap mental berpengaruh signifikan terhadap kinerja karyawan. Hal ini berdasarkan secara simultan diperoleh nilai Fhitung $(11,24)>F_{\text {tabel }}(3,34)$ sehingga hipotesis nol $\left(\mathrm{H}_{0}\right)$ ditolak.

\section{SARAN}

Berdasarkan kesimpulan yang diperoleh, maka saran yang dapat diberikan adalah sebagai berikut:

1. Diharapkan pihak manajemen perusahaan, misalnya dengan mengkondisikan keadaan karyawan, mempertimbangkan faktor kemampuan serta kondisi fisik karyawan. 
2. Diharapkan pihak manajemen perusahaan memberikan motivasi kepada karyawan dengan menaikkan jabatannya sesuai dengan masa kerja juga kinerjanya. Bagi karyawan yang memiliki masa kerja lama dan memiliki prestasi di bidang pekerjaannya maka perlu dipromosikan untuk naik jabatan.

3. Guna meningkatkan hasil pekerjaan yang sesuai dengan ketetapan perusahaan, salah satunya adalah dengan mengintensifkan interaksi dan komunikasi antar karyawan dengan pimpinan sehingga dapat tercipta kerjasama dan suasana yang kondusif yang dapat mendukung kenyamanan dalam bekerja.

4. Untuk mengoptimalkan hasil dari penelitian ini, maka diharapkan penelitian yang akan datang mengenai masalah yang sama bisa menambah variabelvariabel lain yang dipandang relevan dan lebih mendalam lagi pembahasannya, misalnya dengan membedakan tingkat kinerja karyawan pada tiap bagian atau unit kerja. Selain itu semisal memakai kuesioner sebaiknya dalam pengisiannya dipandu ditambah dengan wawancara langsung tiap karyawan yang diteliti sehingga kuesioner nantinya dapat terisi dengan baik dan sesuai dengan kenyataan yang ada di lapangan.

\section{DAFTAR PUSTAKA}

Azwar, S. 2010. Sikap Manusia Teori dan Pengukurannya. Yogyakarta: Pustaka Pelajar.

Hasibuan, Malayu. S.P. 2013. Manajemen Sumber Daya Manusia. (Edisi Revisi). Jakarta. Bumi Aksara.

Martoyo, Susilo. 2012. Manajemen Sumber Daya Manusia. Yogyakarta. BPFE.

Nawawi, Ismail. 2013. Budaya Organisasi Kepemimpinan dan Kinerja. Jakarta: PT. Fajar Iterpratama Mandiri.

Rangkuti, Freddy. 2013. Teknik Membedah Kasus Bisnis Analisis SWOT Cara Perhitungan Bobot, Rating, dan OCAI. Jakarta. Gramedia Pustaka Utama.

Robbins, P.Stephen. 2012. Perilaku Organisasi. Jakarta. Salemba Empat.

Ruky, Achmad. 2012. Sumber Daya Manusia Berkualitas Mengubah Visi Menjadi Realitas: Pendekatan Mikro Praktis untuk Memperoleh dan Mengembangkan Sumber Daya Manusia Berkualitas dalam Organisasi. Jakarta: PT. Gramedia Pustaka Utama.

Soeroto. 2012. Manajemen Sumber Daya Manusia. Jakarta. LP3E.

Sugiyono. 2014. Metode Penelitian Bisnis (Pendekatan Kuantitatif, Kualitatif dan $R \& D)$. Bandung. Alfabeta 